\title{
HANNAH ARENDT E A DESOBEDIÊNCIA CIVIL
}

\author{
Vital Francisco Celestino Alves ${ }^{1}$
}

\section{Resumo:}

Frequentemente, Hannah Arendt trata com destreza e profundidade o "fato político" em suas reflexões. Publicada em 1972, a sua obra Crises da República, oferece quatro interessantes ensaios sobre questões políticas intrinsecamente ligadas à conjuntura política contemporânea e se compromete em instaurar análises de temas de forte apelo à atualidade. Entre eles, um, especificamente, busca analisar e discutir o problema da "desobediência civil". Considerando esse problema, o presente artigo tem como objetivo principal analisar e discutir o problema da "desobediência civil" na teoria política de Hannah Arendt tendo como arrimo teórico a obra Crises da República. Sendo assim, esse estudo se concentrará basicamente em três momentos: no primeiro, será examinado se as figuras de Sócrates e H.D. Thoreau podem ser consideradas expoentes da "desobediência civil"; no segundo, perscrutaremos as distinções entre dois tipos de desobediência: a civil e a criminosa, e, no terceiro, investigaremos as possíveis relações entre a “desobediência civil" e a noção de "consentimento". Assim, almejamos promover uma investigação acerca do fenômeno da desobediência civil e provavelmente estabelecer uma pertinente reflexão.

Palavras-chave: Hannah Arendt. Desobediência civil. Consciência moral. Consentimento.

\section{HANNAH ARENDT AND CIVIL DISOBEDIENCE}

\begin{abstract}
:
Often, Hannah Arendt treats the "political fact" in his reflections with dexterity and depth. Published in 1972, his work Crisis of the Republic, offers four interesting essays on political questions intrinsically linked to the contemporary political situation and is committed to introducing analyzes of topics of strong appeal to the present. Between them, one, specifically, seeks to analyze and discuss the problem of "civil disobedience". Considering this problem, the main objective of this article is to analyze and discuss the problem of "civil disobedience" in Hannah Arendt's political theory having as theoretical support the work Crisis of the Republic. Therefore, this study will basically focus on three moments: in the first, will be examined whether the figures of Socrates and H.D. Thoreau can be considered exponents of "civil disobedience"; in the second, we will look at the distinctions between two types of disobedience: civil and criminal, and, on the third, we will investigate the possible relations between "civil disobedience" and the notion of "consent". Thus, we aim to promote an investigation about the phenomenon of civil disobedience and probably to establish a pertinent reflection.
\end{abstract}

Keywords: Hannah Arendt. Civil disobedience. Moral conscience. Consent.

1 Sou doutor em Filosofia (2017) e mestre em Filosofia (2010) pela Universidade Federal de Goiás (UFG). Realizei entre 2015-2016 estágio doutorado sanduíche na Université Montpellier III e nesse período também participei dos encontros promovidos pelo Centre Rousseau na Université Sorbonne, Paris III. Sou membro do Grupo Interdisciplinar de Pesquisa Jean-Jacques Rousseau e do GT Rousseau e o Iluminismo. Tenho experiência na área de Filosofia, com ênfase em Ética, Filosofia Política e História da Filosofia. E-mail: vitalalves1 @ gmail.com. http://orcid.org/0000-0001-9072$\underline{5002}$ 


\section{Introdução: A desobediência civil em Crises da república}

Em sua obra Crises da república, Hannah Arendt apresenta quatro instigantes estudos nos quais analisa temas políticos de envergadura incontestável, suscitando assim importantes reflexões. Verificam-se nesse livro ensaios concernentes à "mentira na política" e à "violência" e uma profícua entrevista que a autora concedeu ao escritor alemão Adelbert Reif: "Reflexões sobre política e revolução”. Além desses ensaios, também compõe a obra o texto "Desobediência civill", que se expõe de maneira auspiciosa na medida em que Arendt vincula-a como um problema crucial da realidade política dos Estados Unidos. Hannah Arendt reporta a figuras icônicas para pensarmos a respeito da “desobediência civil” como Sócrates e Henry David Thoreau, se empenhando ainda em estabelecer uma interlocução com Alexis de Tocqueville e John Locke, entre outros autores, aos quais ela alude pretendendo, amiúde, valer-se deles como uma espécie de arrimo teórico para confrontar o problema, ou tão somente ambicionando ilustrar a gravidade do que ela se predispôs a analisar. Inicialmente, vemos que, a questão da "desobediência civil" se inscreve como um problema que gravita em torno da órbita da relação entre a moralidade do cidadão com a lei em uma sociedade embasada na ideia de "consentimento". Em vista do pressuposto do "consentimento", a pensadora ao mesmo tempo remete aos contratualistas Hobbes e Rousseau tencionando situar a "desobediência civil” a partir da conjuntura teórica contratualista, exame que a orienta a versar sobre a concepção de "promessa" e fomentar uma reflexão sobre até quando somos "obrigados a cumprir nossas promessas". A diligência teórica arendtiana no que tange à "desobediência civil" e ao percurso que ela adota para realizar sua perscrutação impele-nos as seguintes questões: como podemos pensar o problema da "desobediência civil" tendo como ponto de partida o enlace teórico entre "moralidade" e "legalidade"? De que maneira as imagens de Sócrates e Thoreau podem contribuir para refletirmos sobre a "desobediência civil"? Quais são as prováveis diferenças entre a "desobediência civil" e a "desobediência criminosa"? Sociedades fundamentadas no pressuposto do "consentimento" possibilitam aos cidadãos a liberdade de expressar suas divergências e dão abertura para o emprego da “desobediência civil”? Podemos fixar algum tipo de paralelo entre a "desobediência civil" e o "direito de resistência"? A seguir, almejamos pensar sobre alguns desses problemas que se encontram diretamente ligados ao problema da "desobediência civil".

\begin{tabular}{|l|l|l|l|l|}
\hline Govista Dialectus & Ano 10 & n. 23 & Maio - Agosto 2021 & p. 395 - 414 \\
\hline
\end{tabular}




\section{Sócrates e H.D. Thoreau - consciência moral e desobediência civil}

Até a publicação do artigo "Desobediência civil", de Hannah Arendt, na revista The New Yorker em 1970, as discussões sobre esse tema, em especial na conjuntura norte-americana, pareciam pouco interessar aos filósofos, apresentando-se aparentemente como uma discussão restrita à seara das investigações jurídicas ou sociológicas. Seguramente, um dos maiores méritos do texto de Arendt consiste em tratar da "desobediência civil" mediante uma perspectiva predominantemente filosófica ${ }^{2}$.

Hannah Arendt inicia sua análise sobre a "desobediência civil" defendendo que o referido fenômeno não deve ser compreendido estritamente como um problema de "natureza moral ou legal”, pois o que se encontra em jogo é a questão do poder, não da consciência moral ou da regulamentação das leis. Buscando demarcar sua posição, preliminarmente, a autora de Crises da república, resgata as figuras de Sócrates e Thoreau para assinalar que eles representam o que ela denomina de "júbilo dos juristas", uma vez que "ao que tudo indica" eles consistem em provas "robustas" de que a desobediência à lei apenas pode ser "justificada se o transgressor estiver disposto ou mesmo ansioso a aceitar a punição do seu ato". Arendt parte do pressuposto de que nem o filósofo grego e tampouco o escritor estadunidense podem ser admitidos como arquétipos que encarnam a "desobediência civil". De fato, Sócrates nem mesmo desobedece à lei e Thoreau age por razões de cunho moral ${ }^{3}$.

Sob a perspectiva de Hannah Arendt, observa-se que a "desobediência civil" demanda uma abordagem dotada de especificidade política, logo, se postula a partir de duas características: coletiva e pública. Essas características são fundamentais para que possamos entender a "desobediência civil" pelo viés da filosofia política. Decerto, as ações de Sócrates e Thoreau não correspondem a tais singularidades; vejamos porque exatamente. Tendo em vista que na visão de Hannah Arendt o aspecto coletivo e o elemento público se inscrevem como condição sine qua non da "desobediência civil", evidencia-se que o escopo e sua base teórica se configuram fundamentalmente no âmbito da reflexão política. Estabelecida tal compreensão, a pensadora examina as figuras de Sócrates e Thoreau.

Nesse ponto, estamos em plena conformidade com Helton Adverse (2012).

3 Como demonstrou Marshall Cohen (1972).

\begin{tabular}{|l|l|l|l|l|}
\hline Q & Ano 10 & n. 23 & Maio - Agosto 2021 & p. 395 - 414 \\
\hline
\end{tabular}


As ilustrações sobre as figuras de Sócrates e Thoreau não circundam apenas a bibliografia a respeito da "desobediência civil". Para além das ilustrações, penetra, sobretudo, no imaginário daqueles que assumem a posição de "contestadores civis". De antemão, mesmo Arendt sugerindo que os argumentos empregados por tais figuras para sustentar suas decisões solitárias em conformidade com uma consciência individual repousem na "relação da moral do cidadão com a lei", ela julga mais viável esquadrinhar de que maneira o que foi dito por eles pode contribuir para um debate sobre o tema aqui tratado. O diálogo de Platão crucial para pensarmos a possível contribuição de Sócrates é o Críton, uma vez que as explanações socráticas nessa interlocução evidenciam que o filósofo grego jamais se objetou às leis propriamente ditas, porém direciona uma contestação ao que denomina de um "equívoco judicial”, identificado por ele como uma espécie de "acidente" que o atingiu. No Críton, testemunhamos que a posição adotada por Sócrates diante da tragédia pessoal que lhe abateu não lhe concede o direito de descumprir os "contratos e acordos" firmados com as leis. Torna-se claro, assim, que a querela de Sócrates diz respeito aos juízes e não às leis. O diálogo nos permite atestar igualmente que Críton tentou convencer Sócrates a fugir ou então se exiliar, no decorrer do julgamento, as leis forneciam amparo para a possibilidade do exílio. Rememorando a Apologia, vê-se que Sócrates teve a oportunidade de decidir pela rejeição ao seu julgamento e penalidade, o qual, Hannah Arendt nos lembra, inegavelmente produzia dúvidas concernentes às doutrinas e à moralidade fundamentadas. Mas, da mesma forma que no Críton, na Apologia, Sócrates também expressou sua preferência pela morte ao invés do exílio. Sócrates demonstra que decidir pelo exílio ou pela fuga representaria uma desonra às suas declarações e convicções, escolher uma dessas possibilidades significaria o aniquilamento de toda a sua conduta anterior ao julgamento. Seria uma confirmação da opinião apresentada pelos juízes e uma expressão de que o veredito deles baseava-se em algo justo. Ao contrário da possibilidade de fugir ou de se exilar, Sócrates estabelece a si mesmo e emite aos seus interlocutores o seu desejo de permanecer e morrer. Na interpretação de N. A. Greenberg (1965), o procedimento utilizado por Sócrates se expressa como a prestação de contas de uma "dívida de honra", a conduta de alguém que se arriscou em um jogo, perdeu e decide pagar pelo que perdeu, principalmente porque se agisse de outra maneira não conseguiria mais "conviver consigo mesmo".

\begin{tabular}{|l|l|l|l|l|}
\hline Qonista Dialectus & Ano 10 & n. 23 & Maio - Agosto 2021 & p. 395 - 414 \\
\hline
\end{tabular}


Em relação a Thoreau, embora trate-se de uma narrativa aquém da tragédia socrática $^{4}$, em princípio se apresenta como um exemplo mais adequado em face do debate sobre a "desobediência civil", pois, diferentemente de Sócrates, ele se insurge em oposição à "injustiça das leis em si mesmas". Hannah Arendt adverte, todavia, que a questão desse suposto modelo de contestador civil é que no célebre texto A desobediência civil, de Thoreau, oriundo dessa noite no cárcere e que inseriu a expressão "desobediência civil" no léxico político, notamos uma incursão em um debate que não gravita na esfera da moral do cidadão em relação à lei, e sim na esfera da consciência individual e do compromisso moral da consciência. Para Thoreau, em outras palavras, o homem não tem um dever natural de se dedicar à absolvição de um erro que cometeu, independe de que erro tenha sido, mesmo assim o homem pode vir a ter outros interesses a que se dedicar. O seu dever, na realidade, consiste em não se comprometer com o erro e não fornecer esteio a ele em termos práticos. O que se pode extrair dessa concepção de Thoreau sobre o "erro"? Julgamos que, na visão de Thoreau, a falta de envolvimento de um homem com o erro não é capaz de tornar o mundo um lugar mais confortável. A chegada do homem no mundo não tem como objetivo primordial fazer dele um lugar agradável para se viver, mas para viver nele a despeito do mundo ser um lugar agradável ou desconfortável. Assim como Sócrates, Thoreau empreende sua ação a partir de uma noção de consciência ${ }^{5}$ apolítica, cujas diretrizes, preconiza Arendt, se situam no campo da subjetividade. A finalidade da sua ação se ancora fundamentalmente em termos morais. Não demonstra interesse acerca da maneira como alguns erros implicam em consequências muitas vezes desastrosas para o mundo.

$\mathrm{Na}$ leitura de Hannah Arendt, os verdadeiros desobedientes, isto é, aqueles que assumem o papel de contestadores civis, diferentemente de Sócrates e Thoreau, não possuem inquietações relativas a sua dignidade moral, mas expressam preocupações políticas e com o mundo. Como alternativa, a autora vale-se da figura de Thomas Jefferson. Constata-se nos Political writings, de Jefferson (2004), que nos anos que antecedem a sua morte, ele demonstra duas preocupações: primeira, descobrir recursos ou meios de salvaguardar que os cidadãos do porvir possam desfrutar uma liberdade semelhante àquela que os fundadores do país desfrutavam. Segunda, garantir que o

\footnotetext{
${ }^{4}$ Arendt ressalta que Thoreau pernoitou uma noite na prisão pela recusa em pagar tributos para um governo que consentia com a escravidão. Porém, o escritor americano permitiu que sua tia quitasse o pagamento de seus tributos no dia seguinte.

5 Eis a célebre frase de Thoreau, reportada por Arendt: "a única obrigação que tenho de assumir é a de fazer em qualquer momento aquilo que penso ser o certo".

\begin{tabular}{|l|l|l|l|l|}
\hline Q & Ano 10 & n. 23 & Maio - Agosto 2021 & p. 395-414 \\
\hline
\end{tabular}
}


sistema político preserve o espírito público nos cidadãos vinculando-os intimamente a um governo comum. Independente dos pormenores do programa político delineado por Thomas Jefferson, o que nos parece claro é que Arendt apreende o cerne desse programa, o qual consiste em depositar uma confiança no pressuposto de que a participação ativa dos cidadãos nos assuntos públicos se postula como um pré-requisito decisivo para acautelar a manutenção de um regime político republicano, com efeito, também garantir a liberdade.

Seguindo a interpretação de Helton Adverse (2012), lemos que Jefferson tinha plena consciência de que a preservação da participação popular implicava na fabricação de mecanismos institucionais e o primeiro deles indubitavelmente seria a Constituição. A atribuição primordial dela se configuraria em manter acesso o ardor do espírito público dos cidadãos, a saber, a virtude cívica. Aludindo as reflexões de Jefferson, Arendt estranhamente negligencia a importância crucial da questão "virtude cívica" na constelação das ideias republicanas. Se ela tivesse dado a atenção devida a essa questão teria notado que a frase utilizada por Jefferson na missiva que ele endereça a Thomas Jefferson Smith, isto é, "ama teu vizinho como a ti mesmo e a teu país mais do que a ti mesmo" ressoa a epístola que Maquiavel enviou a Guiccoardini, na qual se lê "amo minha pátria mais do que minha própria alma". Possivelmente, Arendt sabia disso. O que ela parece, de fato, negligenciar, é que os meios sugeridos por Jefferson para salvaguardar a virtude cívica já haviam sido recomendados por Maquiavel nos Discursos sobre a primeira década de Tito Lívio.

O entendimento da "desobediência civil" demanda uma compreensão sobre um provável conflito entre "o homem bom" e o "bom cidadão", assinala Hannah Arendt. A saber, entre o indivíduo particularmente dotado ou não de uma crença a respeito da salvação eterna e o partícipe da comunidade ${ }^{6}$. Se reportarmos a Kant, atestaremos que mesmo uma "raça de demônios" tem a capacidade de dirimir de maneira razoável a questão de se erigir uma constituição caso sejam pelo menos "inteligentes", ou como se depreende hoje, assevera Arendt, o conflito entre moral e política remete a tempos antigos, quiçá mais antigos do que o termo "consciência" que na acepção atual tem uma origem um tanto recente. Assim, as justificativas de Sócrates e de Thoreau para adotarem suas respectivas posições são espreitadas pela autora de Crises da república como

6 Para Aristóteles, o homem tido como "bom" somente poderia ser um bom cidadão em um estado que oferecesse dignidade a seus membros.

\begin{tabular}{|l|l|l|l|l|}
\hline Govista Dialectus & Ano 10 & n. 23 & Maio - Agosto 2021 & p. $395-414$ \\
\hline
\end{tabular}


"antigas". Ela justifica seu ponto de vista sustentando que Thoreau, ao declarar que não se sentia responsável pelo bom andamento da sociedade, revelava uma congruência e, ao mesmo tempo, reconhecia avalizar uma desconsideração ao modelo de "homem bom". Nesse sentido, admite-se que no terreno da moralidade do indivíduo a questão da “desobediência civil" parece ser de outra natureza. As decisões do filósofo grego e do escritor estadunidense são pautadas pela consciência e não podem ser consideradas meramente apolíticas, mais do que isso, elas são com frequência emitidas exclusivamente por uma subjetividade. Portanto, quando Sócrates anuncia que "é melhor sofrer um erro do que cometê-lo", nitidamente ele tenciona demonstrar que isso era melhor para ele, da mesma forma que segundo Sócrates era melhor igualmente "estar em desacordo com multidões do que, sendo um só, estar em desacordo consigo mesmo".

Hannah Arendt avança sua análise sobre esses dois personagens e suas possíveis ligações com a questão da "desobediência civill. Para tanto, recorre, em primeiro lugar, aos diálogos platônicos. Em sua percepção, nos diálogos Górgias, Apologia e Críton, Sócrates não se direciona aos cidadãos. Nessas obras, Platão pela boca de Sócrates, enuncia o meio pelo qual o filósofo desvenda a capacidade que o homem tem de dialogar não apenas com as outras pessoas, mas, além disso, de estabelecer uma comunicação interior, isto é, um diálogo "consigo mesmo". Tal diálogo entre meu ser comigo mesmo delineia o que é denominado por Arendt de "regras da consciência". As referidas regras encontram-se em plena conformidade com aquelas que vemos no texto de Thoreau inscritas em uma abordagem "negativa", ou seja, estabelecem o que "não devemos fazer" ao invés de dizer "o que devemos fazer". As "regras da consciência" não sinalizam os princípios que devem conduzir à ação, designam, ao reverso, os limites que as ações não podem suplantar. Em seus derradeiros diálogos (o Sofista e o Teeteto), Platão buscou aprimorar essa concepção de "diálogo interior" e descreveu "o pensamento como sendo o diálogo silencioso do próprio eu". As "regras da consciência" defende Arendt, pertencem ao interesse que temos a respeito do "eu". Amiúde, seguramente elas vão nos dizer: "evite fazer coisas com as quais não poderás conviver". Essa assertiva engendra um problema legal e político que se desdobra em dois horizontes. O primeiro consiste no pressuposto da não-generalização, isto é, a preservação da sua eficácia delimita-se à esfera da subjetividade. Logo, algo com o que eu não possa conviver não pode afetar a consciência de outrem, posto que, caso afete, consequentemente a consciência estará se opondo à própria consciência. O segundo refere-se ao fato de que a consciência, sendo 
balizada à custa de suas origens antigas, cimenta-se na inferência de que o homem é dotado de uma capacidade inata de distinguir, por um lado, o certo do errado, e, por outro, sugere que o homem se interessa por si mesmo, uma vez que o comprometimento advém estritamente de tal interesse.

As elucubrações que visam alicerçar as atitudes políticas em decisões morais uníssonas, decisões inscritas in foro conscientiae, na visão de Hannah Arendt, se apresentam de forma bastante intrincada devido à junção de ideias inicialmente religiosas e posteriormente seculares, tendo em vista a posição que a ideia de "consciência" adquiriu a partir da preponderância do pensamento cristão. Ponderando acerca da acepção que empregamos no mundo contemporâneo, no campo moral ou legal, podemos reconhecer que a noção de "consciência" se postula de maneira correlata à ideia de "percepção". É possível que a "consciência" individual obtenha uma significação política em circunstâncias hipotéticas nas quais um número razoável de consciências se conflua e seus opositores confiram visibilidade à divergências entre elas expressando-as na praça pública. Em tais situações, todavia, não se tratará mais de indivíduos, tampouco de um fenômeno que corresponde a preceitos oriundos das visões de Sócrates e Thoreau. Preceitos que limitam ao terreno da consciência moral e individual. Nesse caso, as decisões tomadas in foro conscientiae metamorfoseiam-se em opinião pública e ainda que um grupo específico de contestadores civis exponha argumentos que reportem as suas consciências individuais, elas não podem mais serem compreendidas separadamente das demais. Exposto isso, passemos para um exame sobre as prováveis distinções entre "a desobediência civil" e a "desobediência criminosa".

\section{As desobediências: civil e criminosa}

Pelo exposto até aqui, já sabemos que a "desobediência civil” possui dois prérequisitos fundamentais: a publicidade e a coletividade. Isso significa que a "desobediência civil" deve ter como impulso a política, daí a necessidade de ser pública e operada em grupo, ou seja, coletivamente. Hannah Arendt avalia que as condutas de Sócrates e de Thoreau não correspondem a tais pré-requisitos imprescindíveis para o exercício da “desobediência civil”. Por conta dessa avaliação, a pensadora os excluí como possíveis modelos de contestadores civis.

Buscando demarcar as distinções entre a desobediência civil e a desobediência criminosa, Arendt afirma que a desobediência à lei no século XX se 
transformou em um verdadeiro "fenômeno de massa". Ao analisar esse fenômeno sob um enfoque histórico somos levados a crer que ele notabiliza claramente a fragilidade vigente no interior dos governos e sistemas de legislação. Imprimir contestações e desdenhar a autoridade se configura como sintomas indistintos no mundo contemporâneo. Para os juristas, a violação da lei é perpetrada "tanto pelo contestador civil como pelo criminoso". $\mathrm{Na}$ interpretação de McWilliams (1969), é razoável que juristas e, em especial, advogados, pensem que a "desobediência civil", em função de ser desempenhada em público, encontra-se inerente ao desencadeamento de diversos crimes, embora, por um lado, seja evidente que não, e, por outro, que existe uma série de argumentos que desconstroem essa visão, visto que não é somente escasso, mas também irreal que exista algum indício capaz de comprovar que a "desobediência civil”" estimula a predisposição ao crime. Ainda que seja indubitável o fato de os movimentos radicais, e acima de tudo as revoluções magnetizar "elementos criminosos", de acordo com Arendt "não seria correto e nem inteligente identificar os dois", pois os criminosos representam proporcionalmente os mesmos riscos para os movimentos políticos e para a sociedade de maneira geral. Mobilizando-se para deslindar as diferenças entre os dois tipos de desobediência, a autora assevera que podemos compreender "desobediência civil" como designação do fracasso da "autoridade da lei", mesmo que raramente possa ser concebida como sua mola propulsora, a desobediência criminosa se explicita como um efeito inexorável da deterioração da competência e do poder policial.

O fenômeno da “desobediência civil”" se irrompe em situações nas quais uma quantidade expressiva de cidadãos constatam que os meios convencionais para viabilizar mudanças se tornaram ineficazes, que as demandas apresentadas não repercutirão em absolutamente nada, ou, em outro sentido, que o governo ao propor efetivar mudanças demonstra uma insistência em empregar métodos dúbios em termos de legalidade e constitucionalidade. Em vista desses aspectos que contribuem para a irrupção da "desobediência civil", Arendt afirma que existem diversos exemplos nos Estados unidos que comprovam isso, em suas palavras:

Sete anos de guerra não-declarada no Vietnã; a crescente influência dos serviços secretos nos negócios públicos; ameaças abertas ou ligeiramente veladas às liberdades garantidas (...); tentativas de privar o Senado de seus poderes constitucionais seguidas da invasão do presidente ao Camboja em aberto menosprezo à Constituição que exige explicitamente aprovação do Congresso para desencadear a guerra; sem mencionar a nefasta referência do vice-presidente aos resistentes e dissidentes como "abrutes" e "parasitas" (os quais) podemos providenciar para que sejam separados da nossa sociedade sem

\begin{tabular}{|l|l|l|l|l|}
\hline Q Rovista Dialectus & Ano 10 & n. 23 & Maio - Agosto 2021 & p. 395 - 414 \\
\hline
\end{tabular}


maior remorso do que sentiríamos ao jogar fora maçãs podres de um caixote" (ARENDT, 1973 p. 68)

Segundo Arendt, essas últimas palavras utilizadas pelo então vice-presidente Nixon dos Estados Unidos desafiam não apenas as leis do país, mas toda e qualquer ordem legítima. A rigor, a “desobediência civil” pode ser aplicada seja com o intuito de perpetrar vicissitudes indispensáveis, seja para conservar ou restabelecer algo necessário e almejado dentro do próprio status quo. Por exemplo, a luta pela preservação de direitos assegurados por uma Constituição e pelo restabelecimento do equilíbrio entre o poder executivo e os demais poderes, em nenhum desses exemplos pode-se dizer que a "desobediência civil" se compara à desobediência criminosa. Existe uma diferença colossal entre o criminoso que se escamoteia da visão do público e a do contestador civil que se vale da lei e a enfrentar frontalmente. A diferença entre a desobediência frontal à lei, protagonizada em público, e a desobediência escamoteada nos parece tão evidente que apenas será desconsiderada por preconceito ou má vontade. O infrator comum, ainda que esteja ligado a uma facção criminosa, procede em busca da obtenção de uma vantagem a si mesmo, rejeitando se subordinar à aquiescência dos outros, esse tipo de infrator se curvará apenas diante da violência empregada pelos aparelhos repressores do Estado que age em nome da "lei". O desobediente civil, por sua vez, mesmo que habitualmente se inscreva no elenco dos divergentes de uma suposta maioria, conduz-se, na realidade, em prol e pelo benefício de um determinado grupo. Sua ação consiste em um confronto aberto "à lei e às autoridades estabelecidas" na seara da divergência elementar; em oposição à ideia de um indivíduo que busca adquirir um privilégio e retêlo consigo.

Em conjunturas nas quais um grupo de dissidentes detém uma quantidade considerável de membros e ocupa uma posição de destaque, surge uma tendência em rotulá-lo como integrante de uma das maiorias convergentes, isto é, de frações de cidadãos que possuem plena consonância nos roteiros de divergências adotados por eles. Desditosamente, a expressão "maiorias convergentes", nesses casos, passa por uma adulteração ao ser usada em alegações "escravistas e racistas", como sugere o Disquisition on gouvernment, de John C. Calhoun (1947), pois surge tão somente cobrindo interesses, ao invés de proporcionarem um lugar de fala de opiniões $e$ convicções de minorias que se sentem ameaçadas pelas "maiorias dominantes". Hannah Arendt realça que a despeito dessa tendência, a desobediência civil é desempenhada por

\begin{tabular}{|l|l|l|l|l|}
\hline Qovista Dialectus & Ano 10 & n. 23 & Maio - Agosto 2021 & p. 395 - 414 \\
\hline
\end{tabular}


“minorias organizadas" que granjeiam notoriedade em decorrência de suas ações, que não devem ser vistas estritamente pela quantidade de seus membros, mas também pela qualidade de suas opiniões. A pensadora, todavia, está de acordo com Calhoun a respeito do ponto de vista defendido por ele de que em discussões de enorme repercussão nacional, a "convergência ou a aquiescência das várias parcelas da comunidade" apresenta-se como uma condição sine qua non de um arranjo político digno do nome de "constitucional". Logo, enxergar as minorias de desobedientes civis como simplesmente insurgentes ou inconfidentes - no ambiente político estadunidense - se opõe duramente ao glossário e ao espírito da Constituição norte-americana, uma vez que seus criadores demonstravam clara atenção aos riscos de dominação imoderada de uma maioria.

Sob a perspectiva de Arendt, o único instrumento empregado pelos "desobedientes civis" que talvez pudesse dissuadir-nos a retratá-los apenas como insurgentes seria a prática ou uso da violência em suas ações. Porém, outra singularidade inerente à postura imputada a um contestador civil é justamente a "não- violência". Por conta dessa singularidade, "a desobediência civil" não se refere a uma revolução. Uma vez que, o contestar civil reconhece, como assinala Carl Cohen (1996), a autoridade instituída e de maneira geral também a legitimidade da esquematização das leis. Arendt, contudo, problematiza essa questão afirmando que se trata de algo árduo preconizar essa posição, pois “o contestador civil compartilha com o revolucionário o desejo de mudar o mundo" (ARENDT, 1973, p. 70). Tais mudanças que ele ambiciona operar provavelmente se tornarão extremas, a autora, então, toma como exemplo o caso de Gandhi, recorrentemente utilizado como cânone da não-violência nesse tipo de cenário.

Remontando a John Locke, que no Segundo tratado sobre o governo explicita que as coisas do mundo encontram-se em tão contínua mudança que dificilmente as coisas permanecem por muito tempo com o mesmo formato, Hannah Arendt aventa que se a mudança é frequente, intrinsecamente ligada à condição humana, a velocidade das mudanças não pode ser compreendida da mesma forma. Uma vez que a velocidade das mudanças ou transformações pode se diferenciar conforme o país e o século.

Todavia, se as transformações costumavam ocorrer pausadamente durante os séculos, a partir do século XX a velocidade das transformações entrou na ordem do dia. O homem passou a demonstrar uma recorrente sede de mudança, evidentemente que nem a habilidade humana para operar vicissitudes e tampouco a sua destreza em salvaguardar a própria conservação retirou o desejo por estabilidade. Entre o desejo de transformar o

\begin{tabular}{|l|l|l|l|l|}
\hline Q & Ano 10 & n. 23 & Maio - Agosto 2021 & p. 395 - 414 \\
\hline
\end{tabular}


mundo e a precisão de estabilidade, prevaleceu o equilíbrio entre as duas instâncias e a inspeção recíproca. Mas, se houve no referido século um evidente abreviamento dos períodos "entre as gerações", isto é, a espécime convencional de "três ou quatro gerações" no máximo entre pais e filhos se transformou em cerca de "quatro ou cinco anos de diferença na idade", que passaram a ser suficientes para estabelecer um intervalo "entre as gerações", Arendt defende que toda essa mudança fugaz não teria sido viabilizada se não existisse um alicerce hábil o suficiente na sustentação de ambiente apropriado para fluidez das transformações.

Como resultado, o novo cenário, marcado pela velocidade das transformações, instaura uma pertinente discussão sobre o que exatamente essas transformações representam para a ordenação legítima. Mediante o prisma arendtiano, a lei tem a possibilidade de efetivar, e mesmo de regulamentar, uma vicissitude ocorrida, porém, a vicissitude em si emana do campo da excepcionalidade lícita. Remetendo-se à Constituição dos Estados Unidos, a pensadora alega que podemos notar nessa carta constitucional um meio "quase legal" de confrontar a lei, transgredindo-a. Para tanto, buscando se valer de fatos, Arendt afirma que a Suprema Corte, ao decidir sobre as ocorrências levadas a ela, essas decisões seguramente sofrem a influência da opinião pública. Em vista disso, a autora apresenta alguns interessantes exemplos: o primeiro, quando a Suprema Corte recusou-se em deliberar acerca de um projeto de lei que previa examinar a legalidade da Guerra do Vietna $\tilde{a}^{7}$. O segundo, o debate sobre à "Décima Quarta Emenda" gravita de forma bem exemplificadora acerca da conexão entre lei e mudança, pois essa emenda deveria consubstanciar em cláusulas constitucionais a transformação que havia acorrido em consequência da Guerra Civil, entretanto essa tentativa foi rejeitada pelos sulistas inviabilizando assim a igualdade racial. $\mathrm{O}$ terceiro exemplo dado pela teórica política que reforça a inaptidão da lei em instituir mudanças refere-se à "Décima Oitava Emenda", que tem como objeto a "Lei Seca", recusada por

7 Arendt assevera o quão perceptível essa ação impetrada dentro da legalidade se inscreve como efeito da “desobediência civil de recrutas resistentes" que buscavam viabilizar a rejeição dos soldados em relação ao "dever" de ir à guerra. Tentado ilustrar outras ações que podem ser caracterizadas como possíveis exemplos de "desobediência civil" dentro da legalidade, a pensadora acrescenta que praticamente todos os fundamentos das leis trabalhistas estadunidenses foram frutos de contestações. A título de amostra, o direito a firmar acordos salarias, o direito dos trabalhadores se organizarem e fazerem greve. Todas as conquistas desses direitos foram resultados de décadas de "desobediência civil", muitas vezes efetivas com violência diante de leis que haviam se tornadas ultrapassadas.

\begin{tabular}{|l|l|l|l|l|}
\hline Q Rovista Dialectus & Ano 10 & n. 23 & Maio - Agosto 2021 & p. 395 - 414 \\
\hline
\end{tabular}


mostrar-se uma exigência inadmissível ${ }^{8}$. Os exemplos podem se completar ainda com um quarto episódio, trata-se da "Décima Quarta Emenda", pois mesmo sendo firmada legalmente pela Suprema Corte que supostamente combatia leis estaduais claramente opostas à "igualdade racial”, por ela certifica-se que a corte passou a agir efetivamente apenas com a deflagração dos "movimentos de direitos civis". Tais movimentos no que tangia às leis sulistas, se apresentavam inequivocamente como exemplos de "desobediência civil" e repercutiram em profundas metamorfoses nas condutas dos cidadãos negros e, ao mesmo tempo, dos cidadãos brancos. Portanto, convém frisar, que foi somente por meio da "desobediência civil" que os Estados Unidos começaram a entender a gravidade da escravidão e atestar o teor racista de algumas de suas leis. Assim, podemos passar para uma análise sobre a relação entre "desobediência” e lei.

\section{A desobediência civil e a noção de "consentimento"}

No decorrer dos últimos anos, a "desobediência civil”" entrou na ordem do dia das democracias modernas e tudo sugere que ela se inscreveu de forma definitiva nesses regimes políticos ${ }^{9}$ contemporâneos. Pensar sobre a "desobediência civil" pressupõe avaliar a sua relação com a lei. Acima de tudo porque mediante uma compreensão dessa relação talvez possamos definir "se as instituições da liberdade são ou não são bastante flexíveis para sobreviverem ao violento ataque da mudança sem guerra civil nem revolução" (ARENDT, 1973, p. 74). Verifica-se na historiografia acerca da "desobediência civil" e nas discussões que a relacionam à "Primeira Emenda" da constituição estadunidense um reconhecimento da imprescindibilidade de sua ampliação. Partindo dessa verificação, Harrop Freeman (1966) sustenta a necessidade do cultivo da esperança de que as futuras deliberações protagonizadas pela Suprema Corte designem "uma nova teoria em seu lugar". Nicholas Puner (1968), por sua vez, ressalta que de forma evidente a "Primeira Emenda" advoga apenas em nome da "liberdade de expressão e de imprensa", enquanto ao que se refere ao "direito do povo" de realizar reuniões especificamente pacíficas e exigir do governo consideração pelas suas demandas, algo que imputado à "liberdade de ação", encontra-se aberto a diversas explicações e polêmicas.

\footnotetext{
8 Segundo Nicholas Puner (1968), a propagada “desobediência civil” referente à emenda da Lei Seca "não pode por direito ser chamada de desobediência", pois, em sua opinião, ela não era desempenhada em público.

9 Nesse ponto, estamos em perfeita sintonia com Christian Bay (1968).
}

\begin{tabular}{|l|l|l|l|l|}
\hline Qovista Dialectus & Ano 10 & n. 23 & Maio - Agosto 2021 & p. 395 - 414 \\
\hline
\end{tabular}


A questão central da "desobediência civil”, aos olhos de Hannah Arendt, não gravita simplesmente em comprovar se a "desobediência civil" pode ser viabilizada pela "Primeira Emenda", pois a discussão medial refere-se a uma compreensão sobre com qual noção de lei a contestação civil é coadunável. Tomando os Estados Unidos como exemplo no qual o "fenômeno da desobediência civil" encontra-se sobremaneira presente na cultura política, ao escavar as gêneses da ideia de "lei", a pensadora preconiza que tal ideia no país aludido vincula-se diretamente à Revolução Americana, logo, não se trata de um corolário de especulações teóricas, mas, sim, fruto das vivências altamente significativas dos colonos mais antigos. A rigor, o engajamento moral do cidadão em anuir às leis, historicamente advém do axioma de que ele forneceu sua anuência a elas. Ao expressar sua concordância com as leis estabelecidas, o cidadão deixar de se sujeitar a uma vontade que não seja a sua ou uma vontade arbitrária, com efeito, no entendimento arendtiano cada pessoa transita em uma via de mão dupla, isto é, pois “é ao mesmo tempo seu próprio senhor e seu próprio escravo". Esta parece ser a saída apontada por Rousseau e Kant, com os quais Arendt se posiciona contrariamente, visto que esse expediente, ao introduzir um debate sobre a questão do compromisso apresenta uma deficiência, a qual consiste em um retorno à "consciência" individual.

Fixada essa impressão, a análise de Hannah Arendt aventa uma perscrutação concernente à ideia de "consentimento" presente entre os expoentes da tradição contratualista. Entendendo como ponto nevrálgico a afirmação de Eugene V. Rostow (1968), ancorada na defesa de que o importante é considerarmos "o compromisso do cidadão com a lei, numa sociedade de consentimento", a autora recorre na sequência ao pressuposto de Montesquieu firmado na ideia de que o "espírito das leis" se diferencia conforme o país e cada modelo de governo, para argumentar que o "consentimento" depreendido pela acepção de suporte atuante e participação assídua nas questões de natureza pública pode ser atestado no espírito da lei norte-americana. No terreno da especulação teórica, a noção de "consentimento" nessa conjuntura estadunidense inscreve-se como o efeito de um contrato social, o qual, na sua configuração corrente, repousa na ideia de um acordo entre o povo e seu governo e com facilidade tende a ser identificado como uma simples fábula. Todavia, Arendt adverte que tal identificação não corresponde à realidade, posto que na prática revolucionária norte-americana, diversas alianças e convenções foram realizadas tendo início no Pacto do Mayflower e se

\begin{tabular}{|l|l|l|l|l|}
\hline Q & Ano 10 & n. 23 & Maio - Agosto 2021 & p. $395-414$ \\
\hline
\end{tabular}


estendendo até a instalação das trezes colônias no formato de organização social e política.

Examinando a teoria do contrato social, Arendt infere que ao longo do século XVII podem-se comprovar três espécimes de contratos profundamente distintos: o primeiro deles refere-se ao modelo de pacto oriundo das escrituras sagradas, efetuado entre um determinado povo como um todo e seu Deus, embasado na premissa central de que o povo concordava em se sujeitar às leis apresentadas pela divindade. A predominância desse formato de "consentimento" edificaria a teocracia como a forma de governo mais apropriada aos homens. O segundo modelo diz respeito à teoria contratualista de Thomas Hobbes, que apresenta um formato de "consentimento" cimentado no pressuposto de que cada indivíduo firma um pacto com a autoridade fundamentalmente laica almejando salvaguardar sua segurança, para tanto ele abdica de todos os direitos e poderes. Na percepção de Arendt, tal formato é compreendido como uma alternativa "vertical" de pacto social, que seguramente, se mostra discrepante com a realidade política norte-americana de governo, pois exige uma concentração de poder supostamente em nome da proteção de todos aqueles que se encontram subordinados a ele. E nele, os pactuantes não possuem "direitos nem poderes", mas em troca terão sua "segurança" asseverada. Em contrapartida, a república norte-americana, se alicerça no poder do povo, e o poder transferido às autoridades políticas pode, quando o povo julgar necessário, ser suprimido. O terceiro modelo é aquele que lemos no pensamento de John Locke. Pela sua perspectiva, o contrato se configura em uma aliança realizada entre os indivíduos; posteriormente, o compromisso firmado institui reciprocamente um contrato de governo. Arendt denomina o modelo lockeano de alternativa "horizontal" de associação social. A medida que ele, por um lado, restringe o poder dos indivíduos partícipes do pacto, e, por outro, mantem incólume o "poder da sociedade", desse modo, nas palavras de John Adams (1851), se institui um paradigma de governo cimentado em um acordo "original entre indivíduos independentes".

Segundo Hannah Arendt, de maneira geral os contratos se sustentam no princípio da reciprocidade, e comparado às outras formas de acordos, a alternativa "horizontal" se postula naquela em que a reciprocidade perfilha todos os cidadãos aos seus concidadãos. Somente tal formato se mostra hábil o suficiente para conservar o povo coadunado mediante a força de promessas mútuas ao invés de recordações de fatos históricos, ideia de uniformidade como estado-nação ou mesmo pelo modelo do Leviatã 
hobbesiano que suscita a união do povo por meio da intimidação. Em Locke, ao reverso, vê-se que a sociedade preserva-se íntegra ainda que o governo se dissolva ou fomente uma fratura com a sociedade metamorfoseando-se em uma tirania. A partir do momento em que a sociedade existe, o retorno à ilegitimidade e à desorganização presentes no estado de natureza, se tornam improváveis. O autor dos Dois tratados sobre o governo defende que o poder que cada indivíduo forneceu à sociedade ao nela ingressar compromete o indivíduo até ao momento em que a sociedade vier a se dissolver.

$\mathrm{Na}$ interpretação de Arendt, tais palavras de Locke soam como uma "nova versão da antiga potestas in populo", tendo como resultado, diferentemente das abordagens teóricas atinentes à questão do "direito de resistência ${ }^{10 ", ~ e m ~ q u e ~ o ~ p o v o ~}$ apenas tinha direito de agir em situações nas quais estivesse "acorrentado", de que nessa reflexão política o povo possui o direito de obstruir a tentativa de "acorrentamento". No momento em que os protagonistas da Declaração da Independência norte-americana empreendem um esforço bilateral que abrange "suas vidas, fortunas e honras sagradas", tem-se em vista justamente o arcabouçou conceitual exposto por Locke.

A noção de "consentimento" identificada como a atuação voluntária que deve ser abraçada pelos cidadãos pertencentes à sociedade política, na visão de Arendt enquanto especulação parece se postular com exatidão, legalidade e também em uma provável linearidade histórica, porém não é possível postulá-la como “existencial e teoricamente". Isso pode ser explicado pelo pressuposto de que "todo homem nasce membro de uma comunidade particular e só pode sobreviver se nela é bem-vindo e se sente à vontade" (ARENDT, 1973, p. 78). A circunstância inexplicável e fatual de cada recém-nascido subentende algum tipo de "consentimento", isso significa uma concordância com as normas estabelecidas previamente ao seu nascimento. Atesta-se assim que todas as pessoas preservam suas existências mediante um "consentimento" ainda que ele seja tácito, todavia dificilmente poderíamos denominá-lo de "voluntário", pois não é improvável expressar nossa vontade em relação ao que já foi estipulado. Seria "voluntário" se uma criança nascesse em uma sociedade que assegurasse a possibilidade de discordância no âmbito da legalidade no momento em que ela atingisse a vida adulta. A possibilidade de discordância pressupõe o "consentimento" e esse se configura em uma característica de qualquer governo que autointitulado "livre", ora "quem sabe que pode

10 Além de Locke, a questão do direito de resistência é tratada por dois outros filósofos ingleses no século XVII, John Milton e Algernon Sidney.

\begin{tabular}{|l|l|l|l|l|}
\hline Qonista Qialectus & Ano 10 & n. 23 & Maio - Agosto 2021 & p. $395-414$ \\
\hline
\end{tabular}


divergir sabe também que de certo modo está consentido quando não diverge" (ARENDT, 1973, p. 79). Por conseguinte, o "consentimento" presume a garantia do direito de discordância. A partir dessa compreensão, o "consentimento tácito" não pode ser considerado uma ficção, encontra-se intrinsecamente ligado à condição humana. Entretanto, a anuência na esfera do implícito em geral ou propriamente aquilo que Tocqueville denominou de sensos universalis implica em uma separação clara do que entendemos como "consentimento a leis específicas" com as quais não há uma identificação mesmo que seja o resultado de deliberações da maioria.

Amiúde vemos especulações teóricas preconizando que a noção de "consentimento" (consensus universalis) presente na Constituição estadunidense pressupõe simultaneamente o "consentimento às leis estatutárias", posto que em um modelo de governo representativo o povo igualmente contribuiu para elaborá-las. Aqui, a ideia de "consentimento", segundo Arendt, é inteiramente fictícia e equivocada. Sobretudo porque atualmente existe uma "crise no modelo de governo representativo" global e o enfraquecimento dos instrumentos que salvaguardavam a participação dos cidadãos, uma vez que o sistema político fundamentado em partidos instaurou uma cultura da burocratização e a aposta no bipartidarismo deflagrou um sentimento de que os partidos, na realidade, não representam ninguém além de seus mecanismos partidários. Mesmo assim, tanto nos Estados Unidos como no Brasil, o perigo iminente de rebeliões parece não se originar de divergências e oposições a leis provenientes de vontades discricionárias, decretos arbitrários, repressão política inconstitucional e tampouco da notificação dos malefícios provocados pelo establishment verificadas nas práticas mesquinhas em termos de padrões morais daqueles que ocupam altas posições. Hannah Arendt esclarece que a "crise de representatividade" desemboca em uma "crise constitucional" na qual predomina uma perda significativa na confiança pública que depositamos nos processos constitucionais e nas instituições políticas, e inevitavelmente no esfacelamento da noção de "consentimento" e na fortificação intransigente de um discurso antipático de alguns setores da sociedade em assentir com a ideia primordial de consensus universalis.

\section{Considerações finais}

Em sua obra A democracia na América, lançada pela primeira vez em 1835, Tocqueville - ao declarar que o maior perigo para se assegurar a unidade política da 
América em longo prazo não consistia na escravidão, a qual ele pressentiu ser abolida, mas sim nas dificuldades que surgiriam posteriormente com a presença massiva da população negra no território estadunidense -, parece ter prognosticado que o futuro dos negros e dos índios seria tenebroso porque eles jamais seriam incluídos consensus universalis originário da república norte-americana. Arendt testifica a ausência na Constituição estadunidense, e mesmo nos projetos de seus idealizadores, alguma mobilização no sentido de incorporar o povo escravizado no pacto primordial; incluso aqueles que defendiam a emancipação como a via por uma perspectiva baseada na segregação dos negros, ou enxergavam a expatriação deles como uma saída viável. Posição adotada, por exemplo, por figuras emblemáticas como Thomas Jefferson e Abraham Lincoln.

A exclusão dos negros nessa conjuntura da democracia norte-americana, impedindo-os de terem o título de cidadãos ${ }^{11}$, possivelmente encontra-se inerente à conservação do racismo estadunidense, o qual reverberou em meados dos anos 50 do século XX no "Movimento de Direitos Civis dos Negros nos Estados Unidos" marcado por episódios de enorme relevância como "A marcha sobre Washington" e "O verão da Liberdade", assim como contribuiu, ao mesmo tempo, para o advento de grupos beligerantes como os Black Power e os Panteras Negras. O prognóstico de Tocqueville, desditosamente, mesmo após as conquistas alavancadas pelo referido movimento, mantem-se vivo; ele está em recentes casos de pessoas negras, em pleno século XXI. No caso de George Floyd, asfixiado até a morte por um policial branco durante uma abordagem em Minnesota e, no caso de uma mulher negra na Zona sul de São Paulo (o nome da mulher permaneceu em sigilo), que também sofreu pisoteamento por um policial, as vítimas policiais demonstravam perigo algum de reação. Após as abordagens, houve deflagração de diversos protestos de tal modo e em tal intensidade que, na nossa interpretação, se enquadram na seara da "desobediência civil" por atenderem os critérios da publicidade e da coletividade e ainda por se fundamentarem na liberdade de expressão e na liberdade de pensamento; esses são exemplos de que não só a Democracia estadunidense não incluiu os afrodescendentes no seu regime político como, semelhantemente, a jovem Democracia brasileira também não viabilizou a inclusão dos afrodescendentes na sua atmosfera política. Portanto, vê-se que a violência policial contra

11 “Os negros não são e não podem ser cidadãos no sentido da constituição federal”. Declaração da Suprema Corte, em 1857, referente ao Caso Dred Scott. Ver mais em Robert McCloskey (1966).

\begin{tabular}{|l|l|l|l|l|}
\hline Ronista Dialeatus & Ano 10 & n. 23 & Maio - Agosto 2021 & p. $395-414$ \\
\hline
\end{tabular}


afrodescendentes faz parte do cotidiano de estadunidenses e brasileiros, e, sobremaneira, em comunidades carentes marcadas por profundas desigualdades sociais e pela ausência do Estado por meio de políticas públicas. Pensar e viabilizar meios para incluir verdadeiramente os afrodescendentes nos regimes democráticos se apresenta como um desafio permanente e uma demanda urgente para as democracias contemporâneas, as quais, ao negligenciarem essa necessidade de inclusão e produzirem uma real igualdade de condições materiais e de direitos, demonstram a fragilidade e a provável inaptidão do modelo democrático em buscar saídas para enfrentar um problema de gravidade inegável.

\section{Referências}

ADAMS, J. Novanglus. Works, Boston, 1851, v. IV.

ADVERSE, H. Arendt, a democracia e a desobediência civil. Revista Brasileira de Estudos Políticos. Belo Horizonte, 2012.

ARENDT, H. Crises da república. São Paulo: Perspectiva, 1973.

ARISTÓTELES. A política. São Paulo: Martins Fontes, 2002.

BAY, C. Civil disobedience. International Encyclopedia of th social sciences, 1968.

CALHOUN, J.C. A disquisition on gouvernment (1853). New York, 1947.

COHEN, M. Civil disobedience in a constitutional democracy. The Massachussetts Review, 1969.

COHEN, C. Civil disobedience and the law. In: Rutgers law review , v. 21. p.1-17. 1966.

JEFFERSON, T. Political writings. Cambridge: Cambridge University, 2004.

GREENBERG, N.A. Socrates choice im the Crito. Havard studies in classical philology, v. 70, n.1, 1965.

HARROP, A., FREEMAN. Civil disobedience and the law. Rutgers law review, v. 21, p.8, 1966.

HOBBES, Thomas. Leviatã. São Paulo: Nova Cultural, 1997. (Os Pensadores).

HUGHES, G. Civil Disobedience and the political question doctrine. New Yorker University law review, 1968.

LOCKE, John. Dois tratados sobre o governo. São Paulo: Martins Fontes, 2001.

MAQUIAVEL, N. Discurso sobre a primeira década de Tito Lívio. São Paulo: Martins Fontes, 2007.

McCLOSKEY, R. The american supreme court. Chicago, 1966.

\begin{tabular}{|l|l|l|l|l|}
\hline Q & Ano 10 & n. 23 & Maio - Agosto 2021 & p. 395 - 414 \\
\hline
\end{tabular}


McWILliAMS, W, C. Civil disobedience and contemporary constitutionalism. In: Comparative politics. V. I, 1969.

MILTON, John. Political writings. Martin Dzelzains. Cambridge: Cambridge University Press, 1991.

MONTESQUIEU. O espírito das leis. São Paulo: Nova Cultural, 1997. (Os Pensadores).

PLATÃO. Apologia de Sócrates. São Paulo: Nova Cultural, 1997. (Os Pensadores).

Críton. São Paulo: Nova Cultural, 1997. (Os Pensadores).

. Górgias. São Paulo: Nova Cultural, 1997. (Os Pensadores).

. O sofista. São Paulo: Nova Cultural, 1997. (Os Pensadores).

. Teeteto. São Paulo: Nova Cultural, 1997. (Os Pensadores).

PUNER, N. Civil disobedience: na analysis and rationale. New Yorker University law review, 1968.

ROSTOW, E. V. Law, power, and the pursuit of Peace. Harper \& Row, 1968.

ROUSSEAU, J.-J.. Do contrato social. São Paulo: Nova Cultural, 1997. (Os Pensadores).

SIDNEY, Algernon. Discourses concerning government. Indianapolis: Liberty Fund, 1996.

THOREAU, H.D. Civil disobedience. In: THOREAU. The portable Thoreau. London: Peguin, pp.109-137, 1982.

TOCQUEVILlE, A. A democracia na América. São Paulo: Martins Fontes, 2005. 